\title{
20 周年を祝う
}

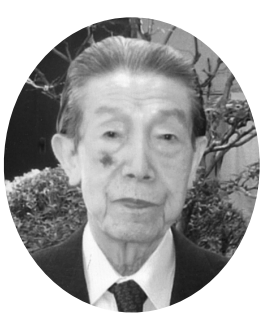

高島 直 一*
20 周年ということでありますが，成形加工ということ を言い出すと，私の生涯にとって，この 20 年というのは 如何なる年月だったのでしょう。私は 1948 年にシべリア の抑留から日本へ鹵ってきました，今年は，私の新しい人 生の還暦にあたります. 1949 年から名古屋市工業研究所 に職を得て, 中小企業のための合成樹脂産業の支援の仕事 につきました，ポリマープロセッシングはそれ以来，今日 までの私の仕事の基盤でした。 60 年の中の最後の 20 年と いうことでこの随想を書きたいと思います

1. 成形加工学会設立までのポリマープロセッシングの歴 史を概観して，それに私の関わりを加えてみますと次の年 表のようになります。

$1942 \star$ Society Plastics Engineer（SPE）設立

1943 瀻維学会設立

1945 太第二次世界大戦終結（広島・長崎原爆投下）

1947 合成樹脂工業技術研究会（後の日本合成樹脂技術 協会）創立

久保亮五『ゴム弾性』出版 (河出書房)

1948 高島（帰国復員）

1949 金丸競『有機材料学』出版

1950 『プラスチックス』誌創刊・工業調査会

1951 太高分子学会設立

1951 村上健吉『単軸スクリューの押出成形理論』

1952 Ziegler 触媒発明

1955 強化プラスチック協会設立, 『プラスチック・エー ジ誌』創刊

1957 日本材料試験協会・レオロジー部門委員会編『化 学技術者のためのレオロジー』刊行（内容：「合 成樹脂の成形のレオロジー」林田建世分担執筆)

スタウディンガーの高分子学説提唱以来, モノマーから ポリマーの重合が盛んになって, サーモプラスチックのプ ロセッシングが押出機, 射出成形機として工業化され始め, 日本にも海外から導入され始めた. ゴム, セルロイド, ベー クライトとしてそれぞれの独立材料が固有の加工法で成形 されていたのに, 戦後は, ポリマーという概念と, 酶酸繊 維素以来の熱可塑成形の機械・生産工業化が合成ポリマー という豊富な成形材料を得て, 一挙にプラスチック時代が

\footnotetext{
* Takashima, Naoichi

高島技術士事務所（元 SPE 日本支部長）

武蔵野市御殿山 1-4-14-504（广180-0005）

2008.5.12 受理
}

現れた感じでした。

そして，『成形加工とは何か』というのが当時の関連技 術者の話題でした。ようやくレオロジーが加工の技術の基 幹になるらしいと思い始めた頃，発足したばかりの高分子 学会の秋季討論会が名古屋で開催された。林田先生ら当時 のレオロジーの先覚者を招いて加工の講演会を企画したと ころ, 高分子学会東海支部長から『成形加工は学問でない から，別の会場で実施するように』と指示された．関係者 は憤湽やる方なかったが，やむをえず別会場で講演会を開 催した。会後の同志の懇談会で，『成形加工を学問にしょ う』という合い言葉が生まれた. 1957 年のことである.

1959.3 月 三菱油化・操業開始, LDPE 生産開始 7 月（高島）名工研から三菱油化(株に移る.

9 月 伊勢湾颱風

$1962 \star$ McKelvey [Principle of Polymer processing] 出版 (1964 邦訳伊藤勝彦)

ネレオロジー懇談会創設（玉虫文一，岡小天，神 戸博太郎，中川鶴太郎ら）

1963 日本 PP 国産化

1965 『プラスチック押出成形ガイドブック』共立出版

1967 PP のエンプラ化可能性発揮（BC-8）

1968 プラスチク・エンサイクロペディア初版（1969 年版）プラスチック・エージ社各年発刊開始

1969 『プラスチック加工技術便覧』日刊工業新聞（高 島 ; 総論執筆)

1970 日本石油化学業界; E. 300, 000 t/y 時代始まる. 太高島，プラスチック・エージ誌新年号座談会の 司会を開始した（*印は座談会のテーマを示す. 時代相を思いだす指標として記載する).

$1971 『 * 70$ 年代のプラスチック産業 一社会変動にど う対応するか一』

$1972 『 *$ 成形加工における質的転換の方向一分子設 計・構造設計・加工技術』

$1975 『 *$ 高分子科学の将来を語る一オイルショック後』

1976 Jackson paper (Thermotropic LCP) 発表

1976 高分子学会創立二十五周年記念講演会 (講演; 『プ ラスチック「フィラー混入改質」の市場動向』を 紹介・高島）

1978 C. Austin [MOLD FLOW] 発売開始. CAE 産 業化

$1979 \star$ Z. Tadmor, C. G. Gogos [Principles of Polymer 
Processing］出版（高島・三菱油化秼退任 $\cdot$ YSE 社長就任)

1980 モレキュラーコンポジット高柳発表（特許出願）

1982 高分子学会編『プラスチック加工の基礎』出版

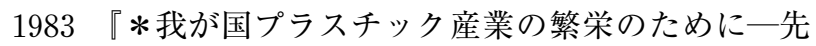
端技術産業のニーズと新材料開発』

ユニチカ, PA/クレー微細複合系特許広告

1984 『*情報化社会におけるプラスチック材料の役割 一技術革新時代の材料研究と加工技術一』

1984 （高島；社長退任・技術士事務所開設）『照于一隅』 『生涯一書生』の心境

$1985 『 *$ 成形加工技術の発展のために一主に射出成形 について（原料企業と機械企業の協力）』

LCP [VECTRA] 発表

丸米国・Polymer Processing Society 設立

太高分子学会で, 初めて成形加工セッション開催. 軽井 沢の夏期大学であった. 今の若い人には判らぬであろ うが, 1957 年以来の念願成就, 引退した加工技術者 も出席して，涙せむばかり感無量であった。

1986 『*プラスチック成形加工技術の展望一データ ベースの整備とコンピュタの応用』 産学共同の 例

(1)米国コーネル大学, (CIMP, コーネルインジェ クションモールディングプログラム) Wang 教 授 (機械工学) が NSF (National Science Foundation）の支援を受けて射出成形の $\mathrm{CAD} / \mathrm{CAM}$ システムの開発

(2)ドイッ,アーヘン大学のIKV (Institute fur Kunststoff-verarbeitung) 機械工学先導

1987 『わが国産業の国際化の加速と部品・下請メー カーの対応, 自動車, 電気, 電子産業を中心に一 (円高による構造失業と国際化・空洞化)』 豊田中央研究所, PA 6/クレーナノコンポジット 発表.

高島；PMC の提唱（プラスチックエージ誌）。成 形加工に打いて，マクロな均質物として扱われる レオロジー体も，内部は PMCであることを認識 して，形を作ることと内部構造を形成・制御する

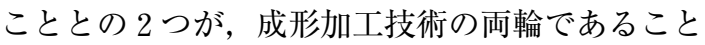
を強調した。

$\star$ PMC (Polymer-Based Micro Composites) 研 究部会設立 (日本工業技術振興協会)

1988 『*伸展する国際化と企業戦略一自動車・電気・ 電子産業とプラスチック産業一』

射出成形 $\mathrm{CAE}$ の活用伸展

12.13 (日本) プラスチック成形加工学会創立

1989 『* 明日のプラスチック材料一 $\mathrm{ABC}$ の花開く一

汎用樹脂のエンプラ化, 大学でポリマープロセッ シングに関心深まる』

4 月 $\star$ PPS 第 5 回国際会議（京都）

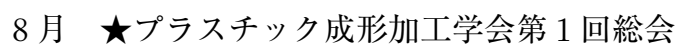

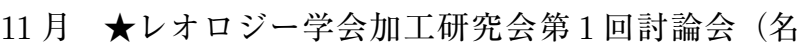
古屋)

生分解性プラスチック研究会発足
L.A.Utracki [Polymer Alloys and Blrnds-Thermodynamics \& Rheology] 出版

1990 『*成形加工技術にみるフロンティア一明日の成 形加工を語る一』

大阪・『花の万博』開催

\section{2. プラスチック成形加工学会創立}

1989 年（平成元年）は日本の成形加工研究元年とも言 うべき華やかな年であった。

1957 年以来高分子学会の中で成形加工の仲間達は, 何 とか学問にしようという希望を持ち続け, やっと認められ た. 1979 年に Z.Tadmor, C. G. Gogos [Principles of Polymer Processing] が出版され，1985 年には高分子夏期大 学で初めて, 成形加工セッションが開催された。私は 1984 年に勤めを離れたので，その後の動きはよく知らなかった が，何とか自分達の発表の場を得たいという動きは急速に 発展したようである. 若い設立世話人の熱意と努力によっ て 1988.12.13 の設立総会に至ったこと, 心から喜んだ.

私は，1984 年以来， 70 歳という年齢制限に阻まれて, ピッチでプレイすることをあきらめて，専らサポーターに 回ることになった。成形加工学会の創設以後の活動につい ては，専らサポーターの立場で応援した。

\section{3 .『成形加工』誌創刊当時の雰囲気}

a 、『プラスチック成形加工学会発足にあたって』(会長・ 山口章三郎 (工学院大学) 記) より抜粋 創立に至る三 つの事情

1. プラスチック成形加工技術の国際性化

(PPS 5 の日本開催が決まって, その対応主体とな ること）

2. 成形加工学の集中化と突出化の必要

単一目標を持つ独立学会を設けて, 研究開発力を

集中的に発揮することが突出的な, 創造的発展に対

してより有効な対策と考えられる。

3 . 新進気鋭の研究者たちの旺盛な熱意

設立の世話人は 30-40 才台を中心とする将来性に

富む新進気鋭の研究者が大多数を占めている.

抱える課題 2 つ,

1. 一学会として分担範囲が狭過ぎないか

2. プラスチック加工法に学術的な開発・発展が望める か

b. 神原周教授祝辞より

「料理と成形加工とはよく似ているが，料理学の話は まだ聞いたことがない，…...」

いずれも成形加工学の構築は難しい事業であることを強 調して叱咤激励の言葉である。私は米国の PPS も設立 5 年を経ていることであるし，設立世話人の多くは，米国で ホワイト教授の指導を受けている人達であるので, 道は見 えていると思っていた．両先生のような心配はしていな かったが, 組織としてのまとまりがどうなるのかを心配し ていた.

成形加工学はどのようになっていったのか, 出発点は創 立三年目に行った第一回基礎セミナーのテーマに見られる. 
§ 第 1 回 基礎セミナー（プラスチック成形加工入門セ ミナー) (1990.7.23)

1. 成形加工の基礎の概説「プラスチック成形加工技術 の史的展開と将来展望」

高島直一

2. 成形加工と高分子レオロジーの基礎との関わり

「成形加工のための流動シミュレーションの基礎」 (九州大学) 船津和守

3 . 成形加工と高分子物理化学の基礎との関わり

「成形加工に扔ける固化過程に及ぼす圧力，流れ， 冷却速度の影響」(山形大学) 小山清人

4. 成形加工と実用特性の基礎との関わり

「ポリカーボネートにおける動的耐久性の影響因子」 (神奈川大学) 大石不二夫

ここから始まって, 学会の会員数は 4 年で 1,000 人に達 した. 社団法人化を達成し，10 周年の記念行事を期に学 会の諸制度を整え, 研究委員会・専門委員会の活躍が始ま るなど，今日まで見事に成長を続けておられる学会の指導 者に敬意を表したい。実はこの 20 年は経済的には，バブ ルが弾けて暗い 10 年に入り，ポリマープロセッシング技 術についても大きく変化の時代であった. 1980 年代から 異種ポリマーのアロイ・ブレンド，異種材料との複合など 反応押出機を使って, 成形材料を自製する動きが多くなり, 材料技術と機械技術が親密に協力し合う機会が多くなっ た. 2006 年に, Tadmor, G. Gogos [Principles of Polymer Processing］の第二版が出版され, 丁度この辺りの変化が 詳しく述べられている.

最近では「ブレンドによるミクロ構造形成」「軸押出機 によるメルト, カオチックミキシング, 反応プロセス」「コ ンパウンディングの技術と理論」など, トップダウン，ボ トムアップの双方からナノ技術への展開につらなってきた。 過去の学際にとらわれない展開である.

さて, 今年の第 19 回年次大会のテーマをみると, 20 年 間の驚くべき変化・展開がよく見える.特に 21 世紀への 展開を担う意気込みに感激する。. 以下に概要を示す.
$\S$ 特別講演

1.『もの造りの進化と課題』新素材の創出, 素材と加 工の融合によるイノベーション

2.『液晶デイスプレイ技術開発の現状と将来』

$\S$ 特別セッション

I . 自動車関連技術の過去 $\rightarrow$ 未来（展示\&後援） (最終的な製品を見据えて」材料・設備・工法・評 価方法を議論する)

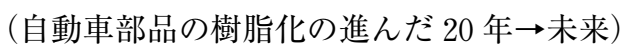

II . 環境関連技術（環境・材料・リサイクル・バイオ材 料などの技術融合）

III. マイクロ・ナノ成形加工技術とその応用展開（ナノ インプリント, 射出成形, 電界紡糸法, 自己組織化 利用など様々な超微細・超精密加工技術などの限界 と現実．またこれらを支える精密金型加工技術，光 学・医療デバイス，各種センサーなど幅広い分野の 成形加工について基礎と工学の幅広い情報など)

IV . 期待される新材料 (高機能性樹脂, ナノコンポジト 樹脂の改質・改善, 新規用途展開, など特異な材料）

$\S$ 一般セッション

1. 射出成形, 2 . 押出成形 (混練を含む), 3 . 紡 糸・フィルム成形，4.超臨界流体利用・発泡成形， 5 .

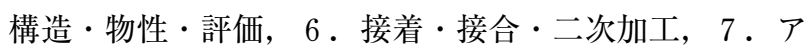
ロイ・ブレンド・複合材料， 8. 工業レオロジー， 9. 成形加工の新たな取り組み

最近, 高分子学会, 繊維学会, 接着学会, ゴム協会など 関連各学会誌を見ると，材料の応用について，科学と技術 の融合テーマが多くなった．各学会がどのように特殊性を だすのか. 難しい時代になってきたように思う.”高分子 工学”とでも称して, 広い科学と技術の融合世界を再組織 化することを考える時代が近いかもしれ如学会員の皆様 のご奮闘を㧍祈りして, 広大な科学技術の世界の展開を 願っております。

「老驥伏歴 志在千里 烈士暮年 壮心不巳」の曹操の 心を思うのみであります。 